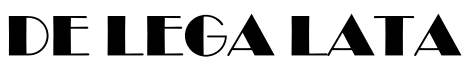

Jurnal Ilmu Hukum

FAKULTAS HUKUM UMSU

\title{
PENYELESAIAN SENGKETA PEMBIAYAAN DENGAN OBJEK JAMINAN HAK TANGGUNGAN PADA BANK SYARIAH DI KOTA MALANG
}

\author{
Nur Islamiyah Puspasari, Novilia Safitri Dewik, Sinta Amipatul Aisiyah, \\ Nur Putri Hidayah
}

Fakultas Hukum, Fakultas Peternakan dan Pertanian, Universitas Muhammadiyah

Jl. Raya Tlogomas No. 246 Malang, East Java, Indonesia 65144

Phone: +62 341 46418-19 (Hunting) Fax.: +62 341460782

Email: nurputri@umm.ac.id (Corresponding Author)

\begin{abstract}
Abstrak
Pada perjanjian pembiayaan, bank sebagai kreditur berwenang meminta pihak nasabah sebagai debitur untuk meletakan jaminan, salah satunya jaminan hak tanggungan berdasarkan Pasal 8 UUPerbankan. Berdasarkan Pasal 20 UU Hak Tanggungan, adanya jaminan hak tanggungan membuat bank dapat melakukan eksekusi terhadap objek jaminan jika debitur wanprestasi. Namun hingga saat ini, belum ada peraturan yang mengatur konkrit mengenai prosedur penyelesaian sengketa perbankan, kecuali peraturan OJK Nomor 1/POJK.07/2014 tentang Lembaga Alternatif Penyelesaian Sengketa di Sektor Jasa Keuangan (POJKLAPS). Permasalahannya, LAPS saat ini hanya ada di Jakarta. Padahal sudah banyak kasus-kasus dimana debitur merasa menjadi korban kejahatan bank karena objek jaminannya dieksekusi tanpa prosedur yang jelas. Penelitian ini bertujuan untuk mengetahui bagaimana prosedur penyelesaian sengketa pembiayaan dengan objek berupa hak tanggungan pada Bank Syari'ah di kota Malang dan Apakah kendala-kendala yang dihadapi dalam proses penyelesaian sengketa pembiayaan dengan objek berupa hak tanggungan pada Bank Syari'ah di kota Malang.
\end{abstract}

\section{Kata Kunci: Sengketa Pembiayaan, Hak Tanggungan, Bank Syariah.}

\section{Abstract}

In financial agreement, a bank as creditor has the authority to ask a client as debtor to place a guarantee such as a mortgage guarantee based on the Article 8 of Banking Regulation. Based on the Article 20 of Law of Mortgage, the availability of mortgage guarantee enables the bank to execute the object of guarantee when the debtor is in default. However, a concrete regulation concerning on the resolution procedure of banking dispute has not been stipulated. The only reference for this issue is the Regulation of OJK (Financial Service Authority) Number 1/POJK/.07/2014 pertaining to the Alternative Institution for Dispute Resolution in Financial Service Sector (POJKLAPS). The problem is, the institution only exists in Jakarta. In fact, there are many cases where the debtors considered themselves as the victim of banking crime due to unclear procedure of the execution of the object of guarantee. This study aimed to investigate the procedure of financial dispute resolution with the object of mortgage guarantee in sharia banks in Malang City and to figure out the constraints encountered during the process.

Keywords: Financial Dispute, Mortgage Guarantee, Sharia Bank.

\section{PENDAHULUAN}

Pemberian pembiayaan pada umumnya terjadi karena salah satu pihak (debitur) membutuhkan bantuan biaya maupun modal kepada pihak yang memberikan fasilitas pembiayaan (kreditur). Bank Syariah adalah salah satu pihak yang memberikan fasilitas 


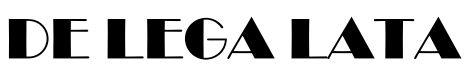

Jurnal Ilmu Hukum

FAKULTAS HUKUM UMSU
Penyelesaian Sengketa Pembiayaan...(Nur Islamiyah, dkk)

Volume 5 Nomor 1, Januari - Juni 2020, 24-36 DOI: https://doi.org/10.30596/dll.v5i1.3371

pembiayaan kepada masyarakat berdasarkan Pasal 19 Ayat (1) huruf (c) UU 21/2008 tentang Perbankan Syariah. Bank Syariah menyalurkan Pembiayaan bagi hasil berdasarkan Akad mudharabah, Akad musyarakah, atau Akad lain yang tidak bertentangan dengan Prinsip Syariah. Akad-akad ini dipakai sebagai pembeda antara perbankan Syariah dengan perbankan konvensional. Letak perbedaan keduanya ada pada penerapan bunga. Pada praktik perbankan syariah, Hukum Islam mengharamkan adanya bunga (riba) pada pinjaman sebagaimana tertuang dalam Al-qur'an Surat Al-baqarah Ayat 275 yang berbunyi:

"Orang-orang yang makan (mengambil) riba, tidak dapat berdiri melainkan seperti berdirinya orang yang kemasukan setan lantaran (tekanan) penyakit gila. Keadaan mereka yang demikian itu disebabkan mereka berkata (berpendapat) bahwa sesungguhnya jual beli itu sama dengan riba. Padahal Allah telah menghalalkan jual beli dan mengharamkan riba. Orang-orang yang telah sampai kepadanya larangan dari Tuhannya, lalu terus berhenti (dari mengambil riba), maka baginya apa yang telah diambilnya dahulu (sebelum datang larangan); dan urusannya (terserah) kepada Allah. Orang yang kembali (mengambil riba), maka orang itu adalah penghuni-penghuni neraka, mereka kekal di dalamnya".

Pemberian pembiayaan, berdasarkan Prinsip Syariah, pihak bank sebagai kreditur wajib mempunyai keyakinan berdasarkan analisis yang mendalam atas itikad dan kemampuan serta kesanggupan nasabah debitur untuk melunasi utangnya atau mengembalikan pembiayaan dimaksud sesuai dengan yang diperjanjikan. Hal tersebut tertuang dalam Pasal 23 (1) UU Perbankan Syariah. Oleh karena itu, untuk menjamin bahwa debitur akan melunasi pinjaman/utang yang diberikan, maka pihak bank mewajibkan debitur untuk meletakan jaminan.

Pemberian fasilitas pembiayaan, akan ada dua perjanjian yang mengikat pihak bank sebagai kreditur dan nasabah sebagai debitur, yaitu perjanjian pokok dan perjanjian tambahan (Setiyono, 2018). Perjanjian pokoknya adalah perjanjian pembiayaan, sedangkan perjanjian jaminan menjadi perjanjian tambahan. Dalam perbankan syariah, perjanjian jaminan dikenal dengan akad kafalah. Menurut Penjelasan Pasal 19 huruf (i) UU Perbankan Syariah, kkad kafalah adalah Akad pemberian jaminan yang diberikan satu pihak kepada pihak lain, di mana pemberi jaminan ( $k a f i l$ )bertanggung jawab atas pembayaran kembali utang yang menjadi hak penerima jaminan (makful).

Adapun bentuk jaminan yang seringkali digunakan dalam praktik pembiayaan adalah jaminan kebendaan (Terok, 2013). Berdasarkan Pasal 1 Angka (26) UUPerbankan Syariah, Jaminan kebendaan yang diletakan oleh debitur dapat berupa benda bergerak maupun tidak bergerak. Dalam praktiknya, yang paling disukai adalah Hak Tanggungan karena objek jaminannya berupa benda tidak bergerak (seperti tanah, rumah, apartemen, dll), yang nilai bendanya semakin lama semakin naik (Mulyanti, 2015).

Pada pelaksanaan perjanjian pembiayaan, tidak semua perjanjian tersebut berjalan lancar. Contoh konkrit adalah saat debitur tidak melakukan prestasi berupa pembayaran angsuran pembiayaan kepada pihak bank. Pada kondisi ini, hak kebendaan yang bersifat sebagai pelunasan hutang (hak jaminan) merupakan hak jaminan yang melekat pada kreditur yang memberikan kewenangan untuk melakukan eksekusi kepada benda yang dijadikan jaminan jika sewaktu-waktu debitur melakukan wanprestasi terhadap suatu prestasi seperti apa yang telah 


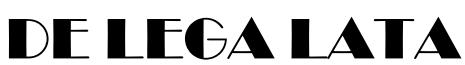

Jurnal Ilmu Hukum

FAKULTAS HUKUM UMSU
Penyelesaian Sengketa Pembiayaan...(Nur Islamiyah, dkk)

Volume 5 Nomor 1, Januari - Juni 2020, 24-36 DOI: https://doi.org/10.30596/dll.v5i1.3371

diperjanjikan, sebagaimana diatur pada Pasal 20 Ayat (1) UU No. 4/1996 tentang Hak Tanggungan (UUHT) (Yasin, 2017).

Tentu saja bank sebagai kreditur tidak serta merta dapat langsung melakukan eksekusi terhadap objek hak tanggungan yang dijadikan jaminan perjanjian pembiayaan antara debitur dan kreditur atas wanprestasi yang dilakukan oleh debitur. Pertama, Bank terlebih dahulu harus melayangkan somasi kepada debitur untuk menyatakan bahwa debitur telah wanprestasi, sebagaimana Pasal 1238KUHPerdata. Namun pasal ini tidak menentukan jumlah peringatan yang harus diberikan oleh kreditur kepada debitur. Dalam praktiknya, ini tentu menjadi ketidakpastian hukum tersendiri karena bisa memungkinkan adanya perbedaan persepsi antara kreditur dan debitur. Kedua, bahwa kreditur baru dapat melakukan eksekusi terhadap jaminan, apabila kreditur pemegang jaminan juga memegang sertifikat hak tanggungan yang memuat irah "Demi Keadilan Berdasarkan Ketuhanan Yang Maha Esa", karena berdasarkan Pasal 20 Ayat (1) huruf (b) UUHT, irah tersebut yang memberikan kekuatan eksekutorial terhadap objek yang dijadikan jaminan.

Ketiga, setiap sengketa yang terjadi antara debitur dengan pihak bank terlebih dahulu dapat diselesaikan melalui proses penyelesaian sengketa secara non litigasi. Latar belakang ketentuan ini merupakan bagian dari rangkaian perlindungan kepada konsumen, dalam hal ini debitur yang merupakan nasabah bank. Ketentuan ini tertuang dalam konsideran Peraturan Otoritas Jasa Keuangan Nomor 1/POJK.07/2014 tentang Lembaga Alternatif Penyelesaian Sengketa di Sektor Jasa Keuangan (POJKLAPS). Permasalahannya adalah bahwa LAPS hingga saat ini hanya berada di Jakarta, dan tidak ada di daerah lain. Hal ini tentu merugikan debitur sebagai konsumen perbankan untuk mendapat solusi terbaik untuk sengketa yang sedang dihadapinya. Keempat, hingga saat ini, tidak ada prosedur konkrit mengenai langkah-langkah penyelesaian sengketa pembiayaan antara nasabah dan bank, baik dalam bentuk peraturan maupun keputusan yang dibuat oleh BI, OJK, DSN, Kementrian Keuangan, maupun pemerintah, presiden bahkan produk yang dibuat oleh DPR beserta Presiden yaitu undangundang (Tolhah, 2015).

Lantas, fakta yang terjadi di lapangan, banyak konsumen perbankan Syariah dalam hal ini debitur yang wanprestasi merasa dirugikan karena adanya ketidakpastian mengenai bagaimana proses penyelesaian sengketa seharusnya berlangsung. Sebagai contoh, pertama, seorang nasabah yang tiba-tiba mendapatkan surat pemberitahuan lelang dari Kantor Kekayaan Negara dan Lelang dimana suratnya berisi akan dilakukan lelang terhadap objek jaminan hak tanggungan, padahal sebelumya nasabah hanya mendapatkan SP1 dan SP3 tanpa ada SP2 (Yunita, 2007). Kedua, Eksekusi rumah yang dilakukan di Purwokerto secara paksa oleh pihak bank padahal prosedur mediasi sedang dilakukan dan tiba-tiba proses mediasi dibatalkan dan dilakukan eksekusi paksa terhadap objek jaminan (Kurniadi, 2015). Ketiga, eksekusi yang dilakukan di Banyuwangi, dimana debitur yang wanprestasi, rumahnya dieksekusi oleh pengadilan, padahal putusan pengadilan belumlah inkracth (Suryono, 2018).

Berdasarkan tidak adanya kepastian hukum mengenai pengaturan tentang prosedur konkrit penyelesaian sengketa pembiayaan dengan objek jaminan hak tanggungan dan fakta banyaknya debitur wanprestasi yang merasa dirugikan karena prosedur yang tidak jelas, menyebabkan penelitian mengenai bagaimana prosedur penyelesaian sengketa pembiayaan dengan objek berupa hak tanggungan serta kendala apa saja yang dihadapi dalam proses E-ISSN: 2477-7889 I ISSN: 2477-653XXI URL: http://jurnal.umsu.ac.id/index.php/delegalata 


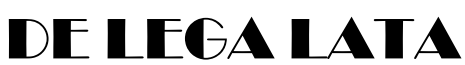

Jurnal Ilmu Hukum

FAKULTAS HUKUM UMSU
Penyelesaian Sengketa Pembiayaan...(Nur Islamiyah, dkk)

Volume 5 Nomor 1, Januari - Juni 2020, 24-36 DOI: https://doi.org/10.30596/dll.v5i1.3371

penyelesaian sengketa pembiayaan dengan objek berupa hak tanggungan, harus dilakukan. Kemudian, mengingat pada sistem perbankan syariah, hanya memberi dan menerima balas jasa berdasarkan perjanjian ( $\mathrm{akad}$ ) bagi hasil. Bank syari'ah akan memperoleh keuntungan berupa bagi hasil dari proyek yang dibiayai oleh bank tersebut. Apabila proyeknya mandek, maka akan dicarikan solusi penyelesaian. (Edhi Satrio Wibowo , Muhammad Syaichu, 2013). Artinya, dikarenakan konsep bagi hasil yang dipakai, sudah sepantasnya apabila ada keuntungan maka pihak bank syariah sebagai kreditur mendapatkan bagian keuntungan, dan apabila terjadi kerugian, pihak bank syariah juga turut menanggung beban. Lantas bagaimana penerapannya di Malang? Oleh karena itu penelitian akan dilakukan pada bank Syariah yang berada di Kota Malang.

Penelitian sebelumnya yang dilakukan oleh Dewi Nurul Musjtari mengenai rekonstruksi lembaga penyelesaian sengketa akad pembiayaan dengan jaminan hak tanggungan pada praktik perbankan syariah pasca Putusan Mahkamah Konstitusi Nomor 93/PUU-X/2012. Yang ternyata dalam penelitiannya menemukan fakta berdasarkan studi kasus yang telah dilakukan oleh peneliti bahwa Sejak adanya Putusan Mahkamah Konstitusi Nomor 93/ PUU-X/2012 terdapat 15 kasus sengketa akad pembiayaan dengan jaminan hak tanggungan dalam praktik perbankan syariah yang diselesaikan melalui Peradilan Agama (sebanyak 8 kasus) maupun Peradilan Umum (sebanyak 7 kasus). (Musjtari, 2016).

Sedangkan penelitian Lutfi Walidani dan Habib Adjie pada Jurnal Res Judicata Mengenai Perlindungan Hukum Kreditur Terhadap Pelaksanaan Eksekusi Hak Tanggungan yang juga mengutip pendapat dari M.Yahya Harahap,dalam bukunya ruang lingkup permasalahan eksekusi bidang perdata,(2009). Bahwasannya proses penyelesaiaan sengketa dengan objek hak Tanggungan secara KUHPerdata (Hukum Positif) dalam pelaksanaan parate eksekusi tunduk kepada Pasal 224 HIR, Pasal 258RBg apabila tidak diperjanjikan kuasa menjual sendiri, penjualan lelang (executoriale verkoop) maka harus diminta kepada ketua pengadilan negeri dan permintaan tersebut berdasarkan alasan cidera janji atau wanprestasi. Sedangkan, Menurut J. Satrio, hak untuk menjual atas kekuasaan sendiri obyek Hak tanggungan kalau debitur wanprestasi merupakan pelaksanaan hak eksekusi yang disederhanakan, yang sekarang diberikan oleh undang-undang sendiri kepada kreditur pemegang hak tanggungan pertama. Dalam arti bahwa pelaksanaan hak seperti itu tidak usah melalui pengadilan dan tidak perlu memakai prosedur hukum acara karena pelaksanaannya hanya digantungkan pada syarat "Debitur Wanprestasi" padahal kreditur sendiri baru membutuhkan kalau debitur wanprestasi.

Kedua penelitian diatas belum ada yang meneliti tentang bagaimana prosedur penyelesaian sengketa pembiayaan dengan objek berupa hak tanggungan pada Bank Syari'ah serta kendala-kendala yang dihadapi dalam proses penyelesaian sengketa pembiayaan dengan objek berupa hak tanggungan pada Bank Syari'ah studi kasus di kota Malang. Adapun rumusan masalah yang diteliti adalah:

1. Bagaimana prosedur penyelesaian sengketa pembiayaan dengan objek hak tanggungan pada Bank Syari'ah di kota Malang?

2. Apakah kendala-kendala yang dihadapi dalam proses penyelesaian sengketa pembiayaan dengan objek hak tanggungan pada Bank Syari'ah di kota Malang? 


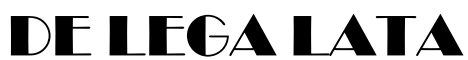

Jurnal Ilmu Hukum

FAKULTAS HUKUM UMSU
Penyelesaian Sengketa Pembiayaan...(Nur Islamiyah, dkk)

Volume 5 Nomor 1, Januari - Juni 2020, 24-36 DOI: https://doi.org/10.30596/dll.v5i1.3371

\section{METODE PENELITIAN}

Jenis penelitian yang dilakukan adalah jenis penelitian hukum empiris dengan menggunakan metode sampling berupa purposive sampling (Efendi \& Ibrahim, 2017). Data akan disajikan dalam bentuk kualitatif. Ditinjau dari sifatnya, penelitian ini merupakan penelitian deskriptif yang dimaksud untuk menberi data seteliti mungkin mengenai prosedur serta kendala yang dihadapi dalam penyelesaian sengketa pembiayaan dengan objek hak tanggungan pada bank Syariah di Kota Malang. Penelitian ini akan di laksanakan di bank syariah di kota Malang. Adapun waktu penelitian dilaksanakan pada bulan Maret 2019 sampai dengan Juni 2019.

Jenis data yang dipergunakan terbagi dua yaitu data primer dan data sekunder. Data primer diperoleh dari hasil penelitian dilapangan terhadap responden maupun narasumber terkait dengan penelitian ini melalui metode wawancara terbuka dan mendalam. Wawancara dilakukan kepada dua Bank Syariah yang memiliki otoritas untuk menentukan bagaimana prosedur penyelesaian sengketa pembiayaan dengan objek jaminan hak tanggung. Bank syariah yang akan menjadi sumber data adalah bank BUMN. Untuk nama bank dirahasiakan karena keduanya tidak berkenan disebut disebut identitas bankb dengan alasan menjaga kerahasiaan bank. Responden pada penelitian ini adalah pegawai bank Syariah yang memahami mengenai bagaimana prosedur penyelesaian sengketa pembiayaan serta kendala apa saja yang ada selama proses penyelesaian sengketa tersebut (bidang hukum). Nama responden dan jabatan dirahasiakan atas permintaan responden. Dalam penelitian ini, responden-responden disebut sebagai Bank Syariah 1 dan Bank Syariah 2.

\section{PEMBAHASAN DAN ANALISIS}

\section{Prosedur Penyelesaian Sengketa Pembiayaan Dengan Objek Hak Tanggungan Pada Bank Syari'ah Di Kota Malang}

Pada dasarnya, sengketa diawali sejak wanprestasi yang dilakukan oleh debitur. Adapun untuk prosedur penyelesaian sengketa, Bank Syariah 1 maupun Bank Syariah 2 sama-sama mendasarinya pada Standar Operasional Prosedur (SOP) yang dimiliki masing-masing bank Syariah. Adapun dokumen SOP menjadi kerahasiaan bank, sehingga baik Bank Syariah 1 maupun Bank Syariah 2 sama-sama tidak mau membuka perihal SOP penyelesaian sengketa pembiayaan kepada peneliti. Adapun norma hukum yang dipakai dalam penyelesaian sengketa pembiayaan dengan objek jaminan hak tanggungan adalah sama-sama menggunakan Pasal 6 UU Hak Tanggungan.

Proses penyelesaian sengketa, Baik Bank Syariah 1 maupun Bank Syariah 2 sama-sama akan memberikan surat peringatan terlebih dahulu kepada debitur. Secara umum, surat peringatan dapat diartikan sebagai bentuk somasi. Uniknya, pada Bank Syariah 1, somasi diartikan berbeda dengan surat peringatan. Bagi Bank Syariah 1, surat peringatan bersifat korespondensi rutin, sedangkan somasi dilakukan jika Bank Syariah 1 memutuskan menempuh jalur penyelesaian secara litigasi. Sedangkan Bank Syariah 2 tidak mengenal perbedaan antara soamsi dan surat peringatan. Adapun untuk jangka waktu yang diberikan, baik Bank Syariah 1 maupun Bank Syariah 2 sama-sama menggunakan istilah "Sesuai asas kepatutan" karena memang tidak ada dasar hukum dalam hukum positif yang mengatur tentang tenggang waktu pemberian surat peringatan/somasi. Rata-rata pihak bank akan memberikan tenggant waktu 7- 


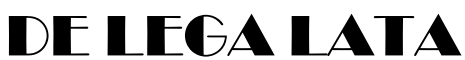

Jurnal Ilmu Hukum

FAKULTAS HUKUM UMSU
Penyelesaian Sengketa Pembiayaan...(Nur Islamiyah, dkk)

Volume 5 Nomor 1, Januari - Juni 2020, 24-36 DOI: https://doi.org/10.30596/dll.v5i1.3371

10 hari untuk setiap surat peringatan (ada surat peringatan 1, surat peringatan 2 dan surat peringatan 3).

Setelah surat peringatan diberikan, respon dari debitur terhadap surat peringatan tersebut merupakan penentu dari bagaimana sengketa tersebut diselesaikan. Jika tidak ada respon sama sekali terhadap surat peringatan yang diberikan, maka Bank Syariah 1 akan melakukan lelang terhadap objek hak tanggungan, atau mengabil jalan litigasi, tergantung karakteristik dari debitur. Sedangkan pada Bank Syariah 2, mereka juga akan melakukan eksekusi lelang, namun terlebih dahulu debitur akan diberikan kesempatan untuk menjual sendiri (agar didapat harga maksimal). Dasar yang digunakan oleh kedua bank Syariah adalah Pasal 6 UUHak Tanggungan dan karena bank Syariah 1 dan bank Syariah 2 sama-sama memegang sertifikat hak tanggungan atas objek jaminan. Khusus bank 1, pengecualian ada pada objek hak tanggungan berupa rumah subsidi, maka Bank Syariah 1 hanya memegang Surat Kuasa Membebankan Hak Tanggungan (SKMHT).

Metode penyelesaian sengketa, pada dasarnya, kedua bank Syariah sama-sama menggunakan jalur non litigasi terlebih dahulu yaitu metode negosiasi. Tentunya jalur ini ditempuh jika debitur memberikan respon terhadap surat peringatan yang diberikan kepadanya. Dalam hal negosiasi, baik Bank Syariah 1 dan Bank Syariah 2 akan memberikan 2 opsi, jika masih mampu melakukan pembayaran maka akan dilakukan restrukturisasi perjanjian, sedangkan jika tidak sanggup maka akan ditawari untuk menjual sendiri objek hak tanggungan atau di lelang pihak bank.

Proses penyelesaian sengketa non litigasi yang dilakukan kedua bank Syariah sama-sama terbatas pada metode negosiasi saja. Tidak dilakukan metode lain seperti mediasi, ajudikasi maupun arbitrase. Selama ini baik pihak bank Syariah maupun konsumen tidak pernah mengajukan permohonan penyelesaian sengketa perbankan ke LAPS. Jika proses penyelesaian sengketa terlalu rumit, maka kedua pihak cenderung mengambil langkah menyelesaikan sengketa melalui jalur litigasi atau ke pengadilan.

Mengenai proses eksekusi objek hak tanggungan, Bank Syariah 1 dan Bank Syariah 2 sama-sama berpegangan pada Pasal 6 UU Hak Tanggungan. Pada Bank Syariah 1 dan Bank Syariah 2, eksekusi melalui lelang akan dilakukan jika: 1) Surat peringatan yang diberikan tidak diindahkan sama sekali. 2) Pihak debitur menolak opsi menjual sendiri objek hak tanggungannya. Hal unik adalah, pada Bank Syariah 1, hampir semua eksekusi yang dilakukan tanpa persetujuan dari debitur, namun pemberitahuan tentang lelang objek hak tangguan tentu telah dikirimkan kepada debitur. Sedangkan pada Bank Syariah 2, masih banyak eksekusi yang dilakukan dengan persetujuan debitur sebelumnya.

Salah satu hal yang membedakan pembiayaan bank syariah dengan bank konvensional adalah hanya memberi dan menerima balas jasa berdasarkan perjanjian (akad) bagi hasil. Bank syari'ah akan memperoleh keuntungan berupa bagi hasil dari proyek yang dibiayai oleh bank tersebut. Apabila proyeknya mandek, maka akan dicarikan solusi penyelesaian. Lantas bagaimana bank Syariah menerapkan prinsip tersebut dalam proses penyelesaian sengketa pembiayaan. Pada Bank Syariah 1, sepenuhnya penerapan prinsip tersebut digantungkan pada kondisi debitur. Apabila debitur tidak sanggup untuk bagi hasil dalam hal ini misalkan debitur mengalami kerugian yang tak terduga, maka debitur dapat mengajukan keringanan. Keringanan disini berupa pengurangan denda atau hal lain seperti perpanjangan masa perjanjian, dan tidak E-ISSN: 2477-7889 I ISSN: 2477-653XI URL: http://jurnal.umsu.ac.id/index.php/delegalata 


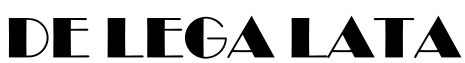

Jurnal Ilmu Hukum

FAKULTAS HUKUM UMSU
Penyelesaian Sengketa Pembiayaan...(Nur Islamiyah, dkk)

Volume 5 Nomor 1, Januari - Juni 2020, 24-36 DOI: https://doi.org/10.30596/dll.v5i1.3371

pada pengurangan pokok utang. Namun, jika wanprestasi terjadi akibat kesalahan pihak debitur, seperti melanggar perjanjian dengan cara mengalihfungsikan pembiayaan yang diberikan, maka tidak akan diberikan keringanan kepada debitur.

Pada Bank Syariah 2, karena akadnya bersifat bagi hasil, maka pihak bank juga harus bertanggunga jawab pada uang yang diperuntukan untuk pembiayaan dengan cara menawarkan 3 langkah penyelesaian. Pertama, negosiasi antara pihak bank dengan debitur. Kedua, apabila tidak ada kesepakatan maka pihak bank akan menawarkan restrukturisasi perjanjian. Ketiga, apabila restrukturisasi perjanjian tidak mungkin dilakukan, maka pihak bank akan menawarkan pilihan terakhir yakni melelang objek jaminan tersebut.

\section{Kendala dalam Proses Penyelesaian Sengketa Pembiayaan Dengan Objek Hak Tanggungan Pada Bank Syari'ah Di Kota Malang}

Pada dasarnya kedua bank Syariah tidak menganggap bahwa keengganan debitur untuk beritikad baik menyelesaikan sengketa melalui jalan damai sebagai suatu masalah. Bahkan upaya perlawanan oleh pihak debitur saat proses eksekusi objek jaminan tidak lagi menjadi sebuah kendala yang sulit karena kondisi tersebut pasti terjadi pada setiap eksekusi. Hal ini dikarenakan pihak bank sudah sangat terbiasa menghadapi karakter debitur yang demikian. Justru yang menjadi masalah, pada proses lelang objek jaminan. Pada Bank Syariah 1, kendala yang kerapkali dihadapi adalah terkait penjualan (pemasaran) objek jaminan hak tanggungan tersebut. Bisa jadi dari kondisi ekonomi masyarakat sekitar yang tidak memungkinkan untuk membelinya, atau dari akses jalan yang tidak mendukung serta tidak adanya listrik, dll. Pada Bank Syariah 2, kendala yang ada sama dengan yang dialami oleh Bank Syariah 2, yaitu kesulitan dalam penjualan objek jaminannya, karena tentunya ada beberapa factor yang mengakibatkan hal tersebut terjadi, misalkan lokasi objek jaminan tersebut berada.

Upaya penyelesaian masalah terhadap kendala di atas, Bank Syariah 1 menyikapinya dengan cara memperluas jaringan pasar dalam penjualan objek jaminan tersebut bisa dengan kerjasama dengan pihak ketika atau dengan pihak agency dan lain sebagainya. Sedangkan Bank Syariah 2 bekerja sama dengan pihak ketiga untuk pemasaran objek jaminan tersebut.

Pada intinya, apabila pihak bank Syariah menghadapi kendala yang tidak bisa diselesaikan oleh pihak Bank maupun bersama dengan debitur, maka langkah yang akan ditempuh baik oleh Bank Syariah 1 maupun Bank Syariah 2 adalah dengan menyelesaikannya melalui metode litigasi atau ke pengadilan. Pada Bank Syariah 1, parameter suatu sengketa diselesaikan melalui metode litigasi adalah ketika debitur sudah tidak mungkin lagi dibina, pembinaan seperti rekstrukturisasi dijual bersama, atau diambil alih keluarga yang mampu, take over dan lainnya telah dilakukan namun masih belum menemukan solusi. Sedangkan pada Bank Syariah 2, akan menempuh metode litigasi jika semua opsi yang ditawarkan pihak bank tidak dapat dipenuhi oleh debitur.

\section{Analisis Prosedur Penyelesaian Sengketa Pembiayaan}

Penetapan kebijakan berupa peletakan hak tanggungan sebagai jaminan pembiayaan dalam praktik perbankan Syariah sudahlah tepat. Akad pemberian jaminan ini dalam hukum Islam disebut sebagai aqad kafalah. Akad kafalah adalah pemberian jaminan yang diberikan satu pihak kepada pihak lain, di mana pemberi jaminan (kafil) bertanggung jawab atas 


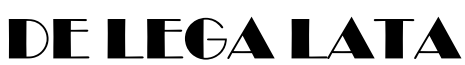

Jurnal Ilmu Hukum

FAKULTAS HUKUM UMSU
Penyelesaian Sengketa Pembiayaan...(Nur Islamiyah, dkk)

Volume 5 Nomor 1, Januari - Juni 2020, 24-36 DOI: https://doi.org/10.30596/dll.v5i1.3371

pembayaran kembali utang yang menjadi hak penerima jaminan (makfullahu). Adapun yang dijadikan jaminan (makfulfihi) dapat berupa orang (Kafalah bi WAjhi) maupun benda (Kafalah bi Mal). Untuk benda, dapat benda bergerak maupun tidak bergerak, melalui gadai, fidusia, hak tanggungan maupun hipotek (Anshori, 2018). Sedangkan dasar hukum penjaminan utang ini terdapat pada Surat Ali Imron ayat 37 yang artinya adalah sebagai berikut "Dan dia (Allah) menjadikan Zakaria kafalahnya atau sebagai penjamin (Maryam)".

Berdasarkan hasil wawancara dengan Bank Syariah 1 dan Bank Syariah 2, dasar hukum yang digunakan jika pembiayaan diberikan dengan objek jaminan berupa hak tanggungan adalah Pasal 6 UU Hak Tanggungan. Dasar hukum yang digunakan tidaklah salah mengingat: pertama, objek jaminan berupa hak tanggungan diperbolehkan dalam Hukum Islam. Kedua, UU Hak Tanggungan tidak memberikan batasan mengenai perjanjian pokok yang tunduk pada UU Hak Tanggugngan. UU Hak Tanggungan hanya mengklasifikasikan bahwa yang tunduk pada UU Hak Tanggungan berdasarkan Pasal 1 Ayat (1) UU Hak Tanggungan adalah semua perjanjian dengan objek jaminan sesuatu yang terkait dengan tanah.

Mengenai proses penyelesaian sengketa, berdasarkan data empiris, hal pertama yang dilakukan oleh Bank Syariah 1 dan Bank Syariah 2 saat debitur wanprestasi adalah mengirimi surat peringatan. Berdasarkan 1328BW, hal ini sudah tepat mengingat kreditur harus memberikan peringatan terlebih dahulu kepada debitur apabila debitur melakukan wanprestasi. Sedangkan untuk jumlah peringatan yang diberikan, kedua bank sama-sama memberikan peringatan hingga 3 kali. Masing-masing peringatan diberikan tenggang waktu kurang lebih 714 hari, yang didasari pada asas kepatutan. Asas kepatutan merupakan salah satu dari delapan asas hukum perikatan nasional. Asas kepatutan menurut subekti (Subekti, 1990) berarti bahwa perjanjian tersebut tidak melanggar perikemanusiaan. Asas kepatutan merupakan pencegah agar tidak ada salah satu pihak yang menindas/merugikan pihak lain dalam sebuah perjanjian. Dalam hukum perjanjian Islam, asas kepatutan ini dapat disamakan dengan asas keadilan atau asas Al-'Adalah yang berarti suatu akad menuntut para pihak untuk melakukan yang benar dalam mengungkapkan kondisi maupun melaksanakan akad, serta harus mendatangkan keuntungan yang adil dan seimbang bagi kedua belah pihak (Anshori, 2018). Penggunaan asas kepatutan sebagai dasar menentukan waktu somasi sudah tepat mengingat hal ini didasari pada bagaimana bank Syariah sebagai kreditur memberikan kesempatan kepada debitur untuk melakukan konfirmasi terhadap wanprestasi dilakukannya.

Setelah surat peringatan tertulis diberikan kepada debitur, maka akan ada dua kemungkinan. Kemungkinan pertama debitur tidak memberikan tanggapan. Jika debitur tidak memberikan tanggapan sama sekali, maka kedua bank Syariah sama-sama akan langsung melakukan tindakan eksekusi terhadap objek hak tanggungan dengan maupun tanpa pemberitahuan kepada pihak debitur. Apakah hal ini salah? Ternyata jika merujuk pada pada Pasal 6 UUHT, hal tersebut tidaklah salah. Objek hak tanggungan sebagai jaminan utang menyebabkan bank sebagai kreditur memiliki kewenangan untuk mengeksekusi dalam sebuah pelelangan dan mendapatkan pelunasan terhadap piutangnya dari hasil lelang objek hak tanggungan tersebut (Luthfi, 2017).

Namun, untuk dapat melakukan eksekusi sendiri, tidak cukup hanya berdasarkan Pasal 6 UUHT namun juga tidak boleh bertentangan dengan Pasal 20 UU HT. Pasal 6 UUHT memang menjadi landasan untuk bank Syariah melakukan penjualan terhadap objek hak tanggungan. E-ISSN: 2477-7889 I ISSN: 2477-653XXI URL: http://jurnal.umsu.ac.id/index.php/delegalata 


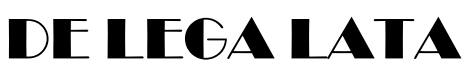

Jurnal Ilmu Hukum

FAKULTAS HUKUM UMSU
Penyelesaian Sengketa Pembiayaan...(Nur Islamiyah, dkk)

Volume 5 Nomor 1, Januari - Juni 2020, 24-36 DOI: https://doi.org/10.30596/dll.v5i1.3371

Namun harus diingat bahwa eksekusi yang dilakukan sendiri oleh pihak bank hanya dapat dilaksanakan jika bank Syariah sebagai kreditur memiliki sertifikat hak tanggungan. Hal ini dikarenakan irah "Demi Keadilan Berdasarkan Ketuhanan Yang Maha Esa" dalam sertifikat hak tanggungan inilah yang memiliki kekuatan eksekutorial. Berdasarkan hasil wawancara pada Bank Syariah 1, ternyata tidak semua objek hak tanggungan memiliki sertifikat hak tanggungan. Pada objek hak tanggungan berupa rumah subsidi, maka Bank Syariah 1 hanya memegang Surat Kuasa Membebankan Hak Tanggungan (SKMHT). Pada SKMHT, tidak ada irah "Demi Keadilan Berdasarkan Ketuhanan Yang Maha Esa" sebagaimana sertifikat hak tanggungan. Artinya, Bank Syariah 1 tidak boleh melakukan eksekusi sepihak terhadap objek hak tanggungan tersebut tanpa kesepakatan dari debitur. Jika tetap dilakukan, berdasarkan Pasal 20 Ayat (4) UUHT, maka eksekusi terdebut batal demi hukum (Hutagalung, 2008).

Kemungkinan kedua adalah debitur memberikan tanggapan terhadap surat peringatan yang diberikan. Pada tahapan ini, kedua bank Syariah akan melanjutkan dengan upaya penyelesaian sengketa melalui jalur non litigasi yaitu negosiasi. Langkah ini sudah tepat mengingat banyaknya keuntungan yang didapat jika sengketa keperdataan diselesaikan dengan cara negosiasi. Negosiasi adalah penyelesaian sengketa yang hanya melibatkan kedua belah pihak, dan hasil akhirnya berupa kesepakatan yang bersifat win-win solution (Wahyuni, 2015). Negosiasi pun diakui sebagai metode penyelesaian sengketa di Indoensia, sebagaimana Pasal 1 Ayat (1) UU Nomor 30 Tahun 1999 tentang Arbitrase dan Alternatif Penyelesaian Sengketa.

Apabila negosiasi berhasil, maka akan ada 2 kemungkinan hasil negosiasi, yaitu restrukturisasi perjanjian (jika debitur masih sanggup melunasi pembiayaan) atau eksekusi objek jaminan (jika debitur sudah tidak mampu melunasi pembiayaan). Restrukturisasi perjanjian dalam Hukum Islam tidaklah dilarang, jika dilandaskan pada asas kebebasan berkontrak yaitu asas kebebasan dan kesukarelaan dari para pihak (Anshori, 2018) maka selama restrukturisasi dilaksanakan dengan dasar sukarela dan tanpa ada paksaan, maka sah untuk dilakukan.

Kemungkinan kedua adalah negosiasi gagal. Jika negosiasi gagal, maka 2 langkah yang akan ditempuh oleh kedua bank Syariah adalah melanjutkan kasus ini ke pengadilan, atau melakukan eksekusi terhadap objek hak tanggungan. Adapun pengadilan yang dipilih kedua bank Syariah adalah pengadilan agama. Pilihan menyelesaikan sengketa pembiayaan perbankan Syariah secara litigasi melalui pengadilan agama sudah tepat, karena telah sesuai dengan kompetensi absolutnya, berdasarkan Pasal 25 Ayat (3) UU No. 48 Tahun 2009 tentang Kekuasaan Kehakiman. Dalam kaitannya menyelesaikan sengketa ekonomi syariah, Pengadilan Agama berwenang pula mengadili tentang tuntutan ganti rugi (ta'wid, daman) baik yang disebabkan oleh adanya wanprestasi ataupun karena adanya perbuatan melawan hukum (Hariyanto, 2014).

Hal yang cukup disayangkan adalah langkah penyelesaian melalui metode litigasi setelah gagalnya proses negosiasi, menurut analisis peneliti adalah terlalu terburu-buru. Analisis ini didasarkan pada masih ada metode penyelesaian sengketa non litidasi lain yaitu mediasi, ajudikasi dan arbitrase. Adapun penyelesaian sengketa melalui non litigasi sejak lahirnya peraturan OJK Nomor 1/POJK.07/2014 tentang Lembaga Alternatif Penyelesaian Sengketa di Sektor Jasa Keuangan (POJKLaps), diselesaikan melalui LAPS. Ruang lingkup LAPS adalah penyelesaian sengketa pada bank Syariah maupun bank konvensional. Adapun metode E-ISSN: 2477-7889 I ISSN: 2477-653XI URL: http://jurnal.umsu.ac.id/index.php/delegalata 


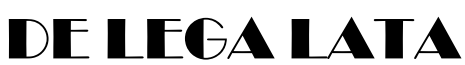

Jurnal Ilmu Hukum

FAKULTAS HUKUM UMSU
Penyelesaian Sengketa Pembiayaan...(Nur Islamiyah, dkk)

Volume 5 Nomor 1, Januari - Juni 2020, 24-36 DOI: https://doi.org/10.30596/dll.v5i1.3371

penyelesaian sengketa yang ditawarkan adalah mediasi, ajudikasi dan arbitrase. Sayangnya, berdasarkan hasil wawancara dengan Bank Syariah 1 maupun Bang Syariah 2, kedua bank sama-sama tidak menggunakan LAPS sebagai perantara penyelesaian sengketa antara bank Syariah dengan debitur. Jika sengketa yang terjadi diantara keduanya semakin pelik, langkah yang diambil pihak bank adalah langsung mengeksekusi atau langsung ke pengadilan. Ini kritik tersendiri untuk LAPS agar mensosialisasikan keberadaan sehingga fungsi dari LAPS lebih maksimal. Setidaknya ada 2 Bank Syariah besar di Kota Malang yang tidak pernah menyelesaikan sengketanya melalui LAPS dan lebih memilih menggunakan metode litigasi, menunjukan LAPS masih belum familiar di Indonesa. Selain itu, berdasarkan penelusuran yang dilakukan, ternyata LAPS hingga saat ini hanya ada di Jakarta, sehingga dapat dipahami mengapa banyak yang enggan bahkan tidak mengetahui keberadaan LAPS sebagai lembaga yang dapat membantu penyelesaian sengketa pembiayaan melalui metode mediasi, ajudikasi maupun arbitrase.

\section{Analisis Kendala-Kendala yang dihadapi dalam Proses Penyelesaian Sengketa Pembiayaan Dengan Objek Berupa Hak Tanggungan Pada Bank Syari'ah Di Kota Malang}

Hasil wawancara kepada Bank Syariah 1 dan Bank Syariah 2, ada 2 (dua) kendala dalam proses penyelesaian sengketa pembiayaan dengan objek hak tanggungan. Kendala pertama, pada proses penyelesaian sengketa yaitu debitur yang tidak lagi dapat dibina (telah dilakukan pembinaan seperti rekstrukturisasi perjanjian, atau objek dijual bersama, atau diambil alih keluarga yang mampu, take over dan lainnya telah dilakukan namun masih belum menemukan solusi), maka langkah yang diambil oleh kedua bank Syariah adalah melanjutkan proses penyelesaian sengketa ke pengadilan agama. Peneliti dapat memahami langkah ini mengingat penyelesaian litigasi memiliki kelebihan tertentu yaitu putusan hakim bersifat mengikat dan eksekutorial, walaupun dalam proses beracara tergugat tidak hadir di persidangan (putusan verstek) (Sunarto, 2015). Kekuatan putusan hakim yang mengikat dan eksekutorial tentu akan menguntungkan pihak penggugat. Namun harus diingat bahwa karena tidak ada batasan waktu terhadap lamanya proses perkara di pengadilan, ditambah dengan adanya upaya hukum baik upaya hukum biasa maupun luar biasa, dapat membuat proses penyelesaian di pengadilan membutuhkan waktu yang lama.

Kendala kedua, pada proses eksekusi yaitu sulitnya proses penjualan objek hak tanggungan, baik proses lelang maupun penjualan di bawah tangan. Penyebab sulitnya objek dijual karena kondisi topografi maupun letak tanah (tidak ada akses jalan, sanitasi jelek, dll). Bank Syariah 1 dan Bank Syariah 2 mensiasatinya dengan cara memperluas jaringan pemasaran. Bagi peneliti, seharusnya hal ini dapat dicegah sedari awal jika bank Syariah sebagai kreditur melakukan survey yang seksama di awal sebelum perjanjian pembiayaan dilaksanakan. Langkah ini merupakan salah cara untuk mengetahui kemampuan calon nasabah sebagaimana Pasal 23 Ayat (1) UU Perbankan Syariah sebelum melakukan penyaluran dana kepada nasabah. 
DE LEGA LATA

Jurnal Ilmu Hukum

FAKULTAS HUKUM UMSU
Penyelesaian Sengketa Pembiayaan...(Nur Islamiyah, dkk)

Volume 5 Nomor 1, Januari - Juni 2020, 24-36 DOI: https://doi.org/10.30596/dll.v5i1.3371

\section{KESIMPULAN}

Peletakan hak tanggungan sebagai jaminan pembiayaan dalam praktik perbankan Syariah sudahlah tepat, sebagaimana aqad kafalah dalam hukum Islam. Saat terjadi sengketa (debitur wanprestasi), langkah awal yang dilakukan kedua bank Syariah adalah memberikan surat peringatan kepada debitur. Apabila surat peringatan tidak ditanggapi, berpijak pada Pasal 6 UUHT, kedua bank Syariah akan langsung melakukan lelang terhadap objek hak tanggungan. Analisis penulis, hal ini sah dilakukan jika pelaksanaannya tidak melanggar Pasal 20 UUHT, fokus dalam hal ini pihak bank Syariah memegang sertifikat hak tanggugan. Ternyata, untuk objek jaminan berupa rumah bersubsidi, pihak bank Syariah hanya memegang SKMHT, artinya apabila bank Syariah melakukan eksekusi terhadap objek hak tanggungan hanya dengan berbekal SKMHT, maka eksekusi tersebut batal demi hukum. Sedangkan jika surat peringatan dari bank ditanggapi oleh pihak debitur, maka akan dilakukan negosiasi antara bank dengan debitur. Jika negosiasi sukses, akan dilakukan restrukturisasi perjanjian (nasabah masih mampu membayar), dan hal ini sah dilakukan karena didasarkan pada asas kebebasan berkontrak dan kesukarelaan dari para pihak. Jika negosiasi gagal, maka akan langsung dilanjutkan ke litigasi melalui pengadilan agama, atau eksekusi objek hak tanggungan. Langkah penyelesaian melalui metode litigasi terlalu terburu-buru mengingat berdasarkan peraturan OJK Nomor 1/POJK.07/2014 penyelesaian sengketa dapat dilakukan di LPAS melalui metode mediasi, ajudikasi dan arbitrase. Berdasarkan hasil wawancara, kedua bank Syariah tidak pernah menyelesaikan sengketa melalui LAPS. Kritik tersendiri untuk LAPS agar mensosialisasikan keberadaan sehingga fungsi dari LAPS lebih maksimal.

Kendala dalam proses penyelesaian sengketa ada 2 yaitu: pertama, debitur yang tidak dapat dibina, maka kedua bank Syariah akan melanjutkan proses penyelesaian sengketa ke pengadilan agama, mengingat putusan hakim bersifat mengikat dan eksekutorial, walaupun dalam proses beracara tergugat tidak hadir di persidangan (putusan verstek). Kedua pada proses eksekusi yaitu sulitnya proses penjualan objek hak tanggungan. Solusi yang dilakukan adalahs memperluas jaringan pemasaran. Sebenarnya hal ini dapat dicegah jika bank Syariah melakukan survey yang seksama sebagai cara mengetahui kemampuan calon nasabah sebagaimana Pasal 23 Ayat (1) UU Perbankan Syariah sebelum melakukan penyaluran dana kepada nasabah.

\section{SARAN}

Bahwa bank syariah hanya dapat melakukan eksekusi lelang objek hak tanggungan tanpa izin dari debitur jika bank syariah memegang sertifikat hak tanggungan, bukan SKMHT. Untuk menjamin sah-nya proses eksekusi, maka dalam aqad kafalah, objek jaminan harus didaftarkan ke Badan Pertanahan Nasional untuk mendapatkan Sertfikat hak tanggungan.

LAPS dapat mensosialisasikan keberadaannya agar masyarakat lebih mengetahui keberadaan dan fungsi LAPS. Selain itu, LAPS sesegera mungkin membentuk cabang di setiap kota/kabupaten agar mempermudah akses bagi debitur maupun kreditur untuk menyelesaikan sengketanya melalui LAPS. 
DE LEGA LATA

Jurnal Ilmu Hukum

FAKULTAS HUKUM UMSU
Penyelesaian Sengketa Pembiayaan...(Nur Islamiyah, dkk)

Volume 5 Nomor 1, Januari - Juni 2020, 24-36 DOI: https://doi.org/10.30596/dll.v5i1.3371

\section{DAFTAR PUSTAKA}

Anshori, A. G. (2018). Hukum Perjanjian Islam di Indonesia (Konsep, Regulasi dan Implementasi). Yogyakarta: Gadjah Mada University Press.

Efendi, J. \& Ibrahim, J. (2017). Metode Penelitian Hukum Normatif dan Empiris. Depok: Prenadamedia Group.

Hapsari, D. R. I.. (2014). Kontrak dalam Kitab Undang-Undang Hukum Perdata dan dan Hukum Islam (Suatu Kajian dalam Asas-asas Hukum). Jurnal Repertorium, 1(1), pp. 8394.

Hariyanto, E. (2014). Penyelesaian Sengketa Ekonomi Syariah di Indonesia. Iqtishadia Jurnal Ekonomi dan Perbankan Syariah, 1(1), pp. 42-58.

Hutagalung, A. (2008). Praktek Pembebanan dan Pelaksanaan Eksekusi Hak Tanggungan di Indonesia. Jurnal Hukum dan Pembangunan, 38(2), pp. 148-174.

Kurniadi, R., (2015). Apakah Kami Korban KEjahatan BAnk. [Online] Available at: https://www.kompasiana.com/rudi99/550e1779a33311a92dba7dfb/apakah-kamikorban-kejahatan-bank [Accessed 10 April 2019].

Walidani, Lutfi, Habib Adjie. (2018). Perlindungan Hukum Kreditur Terhadap Pelaksanaan Eksekusi Hak Tanggungan. Res Judicata, june, 1(1), pp. 47-56.

Marnita, 2016. Eksekusi Jaminan Hak Tanggungan Sebagai Upaya Penyelesaian Pembiayaan Bermasalah. FIAT JUSTICIA, 10(3), pp. 525-544.

Mulyanti, W. (2015). Pengaruh Konsolidasi Lahan Perkotaan terhadap Harga Tanah di Ringintelu, Kelurahan Kalipancur - Kota Semarang. Jurnal Pembangunan Wilayah dan Kota, 11(1), pp. 63-75.

Musjtari, D. N. (2016). Rekonstruksi Lembaga Penyelesaian Sengketa Akad Pembiayaan Dengan Jaminan Hak Tanggungan Pasca Putusan Mahkamah Konstitusi Nomor 93/PUUX/2012. Jurnal Media Hukum, june, 23(1), pp. 62-75.

Setiyono, G. C. (2018). Jaminan Kebendaan dalam Proses Perjanjian Kredit Perbankan (Tinjauan Yuridis Terhadap Jaminan Benda Bergerak Tidak Berwujud). Jurnal Transparansi Hukum, 1(1), pp. 1-18.

Soekanto, S. (2007). Pengantar Penelitian Hukum. Jakarta: UI Press.

Subekti. (1990). Hukum Perjanjian. Jakarta: Intermasa.

Sunarto. (2015). Peran Aktif Hakim dalam Perkara Perdata. 2 ed. Jakarta: Kencana.

Suryono, E. (2018). Eksekusi Rumah Sengketa Anggota DPRD Banyuwangi Berujung Ricuh. Available at: https://www.inews.id/daerah/jatim/eksekusi-rumah-sengketa-anggotadprd-banyuwangi-berujung-ricuh/353122

[Accessed 20 April 2019].

Terok, G. (2013). Fungsi Jaminan dalam Pemberian Kredit. Lex Privatum, 1(5), pp. 5-16.

Tolhah, A. (2015). Peluang Dan Tantangan Kompetensi Peradilan Agama Pasca Amandemen Undang-Undang Nomor 7 Tahun 1989 Tentang Peradilan Agama. Asy-Syariah, 17(2), pp. 123-138.

Wahyuni, D. (2015). proses Negosiasi Dalam Kerjasama PT Arina Multikarya dengan PT Rama Indonesia. WACANA Jurnal Ilmiah Ilmu Komunikasi, XIV(2), pp. 164-182. 
Jurnal Ilmu Hukum

FAKULTAS HUKUM UMSU
Penyelesaian Sengketa Pembiayaan...(Nur Islamiyah, dkk)

Volume 5 Nomor 1, Januari - Juni 2020, 24-36 DOI: https://doi.org/10.30596/dll.v5i1.3371

Wibowo, Edhi Satrio, Muhammad Syaichu. (2013). Analisis Pengaruh Suku Bunga, Inflasi, Car, Bopo, Npf Terhadap Profitabilitas Bank Syari'ah. Diponegoro Journal of Management, 2(2), pp. 1-10.

Yasin, M. N. (2017). Pragmatisme Perbankan Syari'ah Dalam Penyelesaian Eksekusi Objek Hak Tanggungan Studi Putusan Nomor 116/Pdt.Plw/2015/PN.Kpn. Al-Ihkam, 12(1), pp. 42-64.

Yunita, M. A. (2007). Prosedur Lelang Jaminan. [Online] Available at: https://www.hukumonline.com/klinik/detail/ulasan/cl7020/prosedurlelang-jaminan-kredit

[Accessed 18 Maret 2019].

Undang-Undang Republik Indonesia Nomor 4 Tahun 1996 tentang Hak Tanggungan

Undang-Undang Republik Indonesia Nomor 30 Tahun 1999 tentang Arbitrase dan Alternatif Penyelesaian Sengketa.

Undang-Undang Republik Indonesia Nomor 21 Tahun 2008 tentang Perbankan Syariah.

Peraturan Bank Indonesia Nomor 9/19/PBI/2007 tentang Pelaksanaan Prinsip Syariah dalam Kegiatan Penghimpinan Dana dan Penyaluran Dana serta Pelayanan Jasa Bank Syariah

Surat Edaran Bank Indonesia Nomor 10/14/DPbS perihal Pelaksanaan Prinsip Syariah dalam Kegiatan Penghimpunan Dana dan Penyaluran Dana serta Pelayanan Jasa Bank Syariah 